Dept. of Food Hygiene,

Animal Health Research Institute.

\title{
PREVALENCE OF SOME AEROBIC AND ANAEROBIC PSYCHROTROPHS IN VACUUM-PACKED MEAT WITH SPECIAL REFERENCE TO L. MONOCYTOGENES
} (With 3 Tables)

\author{
By \\ JEHAN MAHMOUD MAHMOUD OUF
}

(Received at 12/5/2010)

مدى تواجد الميكروبات المحبة للبرودة والميكروبات اللاهوائية فى منتجات اللحوم

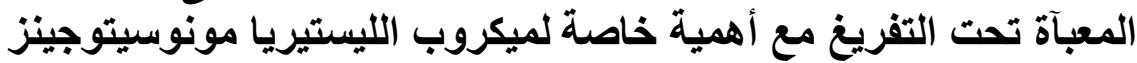

\section{جيهان محمود محمود عوف}

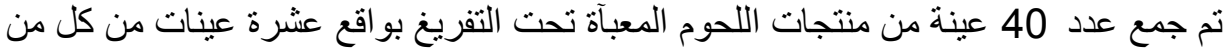

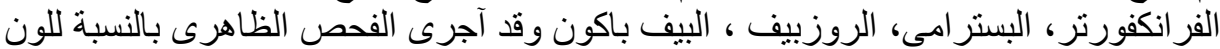

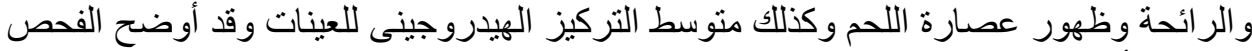

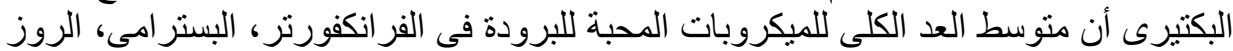

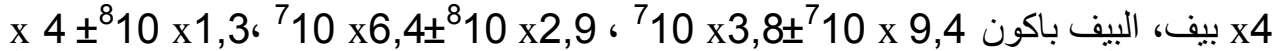
810 x1,6

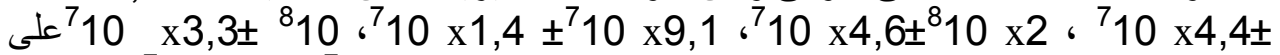
التو الى وكان متوسط العد الكلى للميكروبات اللاهو ائية

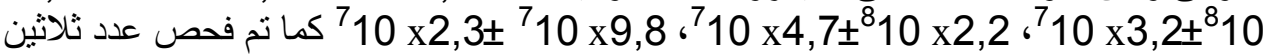

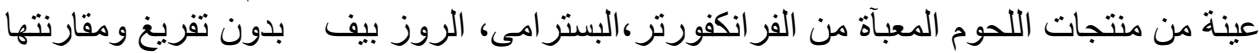

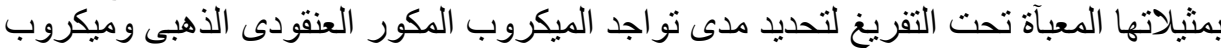

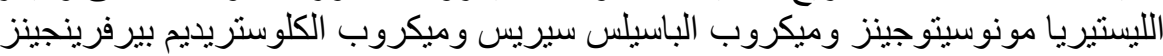

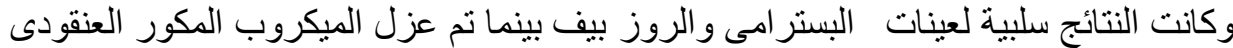

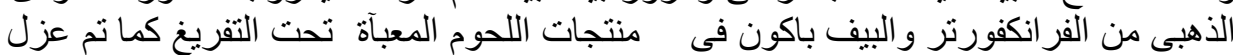

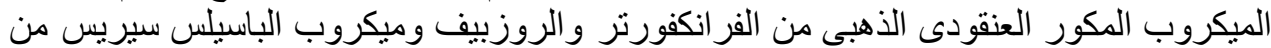
الفر انكفورترو البستر امى فى منتجات اللحوم المعبآة بدون تفريغ الروزيغ

\section{SUMMARY}

Forty samples of four vacuum-packed meat products (ten each of frankfurter, pastrami, rose beef and beef bacon) were collected from different wholesale retail outlets at Cairo and Giza Governorates. The samples were assessed in terms of colour, odour, appearance of released 
meat juice and $\mathrm{pH}$ measurement and examined for psychrotrophic, lactic acid bacteria and anaerobic counts. The mean psychrotrophic counts were $9.4 \times 10^{7} \pm 3.8 \times 10^{7}, 2.9 \times 10^{8} \pm 6.4 \times 10^{7}, 1.3 \times 10^{8} \pm 4 \times 10^{7}$ and $10^{8} \pm 3 \times 10^{7} / \mathrm{g}$ respectively, while the mean counts for lactic acid bacteria were $1.6 \times 10^{8}$ $\pm 4.4 \times 10^{7}, 2 \times 10^{8} \pm 4.6 \times 10^{7}, 9.1 \times 10^{7} \pm 1.4 \times 10^{7}$, and $10^{8} \pm 3.3 \times 10^{7} / \mathrm{g}$ respectively. Also the mean anaerobic counts were $9.7 \times 10^{7} \pm 1.8 \times 10^{7}$, $1.8 \times 10^{8} \pm 3.2 \times 10^{7}, 2.2 \times 10^{8} \pm 4.7 \times 10^{7}$ and $9.8 \times 10^{7} \pm 2.3 \times 10^{7} / \mathrm{g}$ respectively. Another thirty samples of packed frankfurter, pastrami, rose beef were examined and compared with the aforementioned vacuum frankfurter, pastrami, rose beef products for detection of S.aureus, L. monocytogenes, $B$. cereus and $\mathrm{Cl}$. perfringens. S. aureus could be detected in vacuum packed frankfurter and beef bacon samples while in resembling packed samples $S$. aureus and B. cereus could be isolated.

Key words: Meat products, vacuum-packed meat, psychrotrophs, L.monocytogenes

\section{INTRODUCTION}

Food packaging serves to protect products against deteriorative effects, contain the product, communicate to the consumer as a marketing tool, and provide consumers with ease of use and convenience (Yam et al., 2005). The display of meat in plastic materials allows consumer evaluation of the product in an attractive, hygienic and convenient package (Renerre and Labadie, 1993). Packaging of food now performs beyond the conventional protection properties and provides many functions for the contained product (Han, 2005a).

Modern meat packaging techniques are intended to maintain microbial and sensory quality of the product. Product shelf-life can be extended by inhibiting or retarding the growth of undesirable microflora. This can be achieved by manipulation of the meat microenvironment (Hotchkiss, 1988). It is well known that packaging makes food more convenient and gives the food greater safety assurance from microorganisms, biological and chemical changes so that the packaged foods may have a longer shelf life. As a result, packaging has become an indispensable element in the food manufacturing process in order to meet the huge demand of the food industry (McMillin, 2008).

Modified atmosphere packaging (MAP) is the removal and/or replacement of the atmosphere surrounding the product before sealing in vapor-barrier materials. MAP can be vacuum packaging (VP), which 
removes most of the air before the product is enclosed in barrier materials, or forms of gas replacement, where air is removed by vacuum or flushing and replaced with another gas mixture before packaging sealing in barrier materials. The headspace environment and product may change during storage in MAP, but there is no additional manipulation of the internal environment (McMillin et al., 1999).

Packaging ranged from overwrap packaging for short-term chilled storage and/or retail display to barrier packages for longer terms of chilled storage or display (Kerry et al., 2006). In such packaging, an initial atmosphere is generated by either permitting air to be enclosed or by injecting a desired initial gas mixture. This blend then changes as a result of multiple variables including: (i) permeation of oxygen, carbon dioxide, and water vapor through the package material; (ii) transmission of oxygen, carbon dioxide, and water vapor through the seal and defective structural areas; (iii) temperature of the package material which may lead to small changes in permeation; (iv) surface area of the package material; and (v) thickness of the package material (Tsigarida and Nychas, 2001). Such changes may influence/affect the contribution of different members of microbial association and as a consequence, an extension of shelf life can be achieved. Despite the extended shelf life of refrigerated products stored under vacuum pack/modified atmosphere packaging conditions there is an increased concern about the growth/survival of microaerophilic psychrotrophic pathogens (Garcia de Fernando et al., 1995).

Success and continuation of the many different retail MAP formats has been dependent upon product, package, and system interactions, relationships of processors and retailers, and consumer acceptance of the merchandising format (Brody, 2002). Meat spoilage is a complex process in which microorganisms present in the muscular tissue due to secondary contamination during processing are involved, and which depends on ambient temperature. The storage of meat is associated with changes in quality resulting from microbial activity, shift of $\mathrm{pH}$, production of toxic substances, and aberrant odor (Huis, 1996). Lactic acid bacteria appeared to be more resistant and they became the dominant component of the microflora during chilled storage (Farkas et al., 1996).

Typical microbial flora responsible for anaerobic spoilage of meat is lactic acid producing bacteria (LAPB) of the genus Lactobacillus (Huis, 1996). LAPB, including the genera Lactobacillus and Leukonostoc, predominate in meat stored under anaerobic condition. 
Anaerobic decomposition of meat is a slow process setting in as soon as the bacterial population reaches $10^{8}$ to $10^{9} \mathrm{CFU} / \mathrm{g}$. Shelf life can be shorter if the hydrogen sulphide-producing species Lactobacillus sakei prevails (Pipek, 1995). The lactobacillar population on meat usually includes the species of L. sakei, L. curvatus, and L. plantarum (Hugas, 1998).

As a result of dominating of flora by lactic acid bacteria, the shelf life might be extended. That is because lactic acid bacteria are considered harmless, although adventitious growth of certain types of lactic acid bacteria may cause spoilage due to accumulation of undesirable metabolites (Gould, 1996).

Vacuum-packed meat products supported S.aureus growth and cannot be considered shelf stable. The product $\mathrm{pH}$ and moisture-protein ratio were the compositional factors best correlated with $S$. aureus survival and growth, but $\mathrm{pH}$ and $\mathrm{a}_{\mathrm{w}}$, or $\mathrm{pH}$ and water-phase salt also may provide useful predictive guidance for $S$. aureus growth (Ingham et al., 2005).

Alisarlim et al. (2005) stated that because of high level of L. monocytogenes contamination in vacuum packaged processed meat products, it is essential to make sure that all necessary sanitary requirements be met to avoid any contamination. Inadequate cooking practices or raw consumption of these contaminated products may cause potential risks for public health.

B. cereus is a common contaminant of food processing environment and is, therefore, of concern to the meat industry. It can produce a heat sensitive enterotoxin, which produce diarrheal syndrome and a heat resistant one induces a vomiting syndrome (Hayes, 1992).

Ray et al. (1989) added that a Clostridium sp. was associated with spoilage of the vacuum-packed beef and that it produced extensive proteolysis, loss of texture, foul odor and bright red to reddish-green color in meat.

\section{MATERIALS and METHODS}

\section{Collection of samples}

Forty samples of four vacuum-packed meat products (ten of each, Frankfurter, Pastrami, Rose beef and Beef bacon) were collected from different wholesale retail outlets at Cairo and Giza cities. The collected samples were transferred immediately to the laboratory in an icebox with minimum period of delay to be subjected to the following examinations: 


\section{1- Sensory assessment:}

The samples were assessed in terms of colour, odour and appearance of released meat juice using three description for each characteristic with the following verbal definitions (Napravnikova et al., 2002):

Colour 1- fresh, light pink

2- moderately altered

3- markedly altered, grayish to greenish

Odour 1-typical of meat product

2- agreeable, milky

3- repulsive, typical of beginning spoilage

Meat juice 1- no released juice

2- small amount, lightly opalescent

3- markedly turbid, dense to sticky

pH: It was determined using pH meter (Digital, Jenco 609)

\section{2- Bacteriological examination:}

2.1 Preparation of samples: The technique recommended by FDA (2001) was followed where ten grams of samples to which $90 \mathrm{ml}$ of $1 \%$ sterile buffered peptone water (Oxoid CM9) were aseptically added to provide a dilution of 1/10, then the content of the bag was stomached for 60 seconds using stomacher (stomacher lab. Blender 400, Seward Lab. Serial No. 30469 type BA 7021, London), then 10 fold decimal dilutions were prepared up to $\left(10^{-7}\right)$.

\subsection{Bacterial count:}

2.2.1 Pyschrotrophic count was done using plate count agar at $17^{\circ} \mathrm{C}$ for 16 hours then at $7^{\circ} \mathrm{C}$ for 3 days according to $\operatorname{APHA}(1992)$

2.2.2 Lactic acid bacteria count using MRS agar (de Man-Rogosa-Sharpe agar) at $30^{\circ} \mathrm{C}$ for 72 hours in anaerobic jar was determined according to APHA (1992)

2.2.3 Anaerobic count was done using Reinforced Clostridia agar at $37^{\circ} \mathrm{C}$ for 48 hours in anaerobic jar according to Gibbs and Freame (1965).

2.3 Isolation and 1dentification of some pathogens: 
2.3.1 Isolation and identification of Staphylococcus aureus was carried out according to Food and Drug Administration FDA (2001)

2.3.2 Isolation and identification of Listeria monocytogenes was done according to FDA (2003)

2.3.3 Isolation and identification of Bacillus cereus outlined by FDA (2001)

2.3.4 Isolation and identification of Clostridium perfringens according to the recommended methods described by APHA (1992) was carried out.

Another thirty samples of packed frankfurter, pastrami, rose beef were examined for detection of $S$. aureus, L. monocytogenes, B. cereus and $C l$. perfringens and compared with aforementioned examined vacuum products of the same types for presence of these microorganisms.

\section{RESULTS}

Table 1: Mean values of sensory descriptors of the examined vacuum packed meat products $(\mathrm{No}=10)$

\begin{tabular}{|c|c|c|c|c|c|c|c|c|c|c|c|c|}
\hline \multirow{5}{*}{$\begin{array}{c}\text { Sensory } \\
\text { Descriptor }\end{array}$} & \multicolumn{12}{|c|}{ Meat Products } \\
\hline & \multicolumn{3}{|c|}{ Frankfurter } & \multicolumn{3}{|c|}{ Pastrami } & \multicolumn{3}{|c|}{ Rose Beef } & \multicolumn{3}{|c|}{ Beef Bacon } \\
\hline & \multicolumn{3}{|c|}{ Storage period $(28)^{*}$} & \multicolumn{3}{|c|}{ Storage period(53) } & \multicolumn{3}{|c|}{ Storage period $(38)^{*}$} & \multicolumn{3}{|c|}{ Storage period $(60)^{*}$} \\
\hline & \multicolumn{3}{|c|}{$\mathrm{pH}$} & \multicolumn{3}{|c|}{$\mathrm{pH}$} & \multicolumn{3}{|c|}{$\mathrm{pH}$} & \multicolumn{3}{|c|}{$\mathrm{pH}$} \\
\hline & $\begin{array}{l}5.2- \\
5.51\end{array}$ & $\begin{array}{c}5.53 \\
5.81\end{array}$ & $\begin{array}{l}5.84 \\
6.16\end{array}$ & $\begin{array}{l}5.2 \\
5.6\end{array}$ & $\begin{array}{l}5.53 \\
5.81\end{array}$ & $\begin{array}{l}5.84- \\
6.16\end{array}$ & $\begin{array}{l}5.2- \\
5.51\end{array}$ & $\begin{array}{c}5.53- \\
5.81\end{array}$ & $\begin{array}{c}5.84- \\
6.16\end{array}$ & $\begin{array}{l}5.2- \\
5.51\end{array}$ & $\begin{array}{l}5.53- \\
5.81\end{array}$ & $\begin{array}{l}5.84- \\
6.16\end{array}$ \\
\hline Colour & 2 & 1.5 & 1.5 & 1 & 1 & 1.5 & 1.5 & 1 & 2 & 2.5 & 2 & 2 \\
\hline Odour & 2 & 2 & 2 & 1 & 1 & 1.5 & 1.5 & 1 & 1.5 & 2 & 1.5 & 2 \\
\hline Meat juice & 2.5 & 1.5 & 2 & 1.5 & 1.5 & 2 & 2 & 1.5 & 2 & 2 & 2 & 2 \\
\hline
\end{tabular}

* Mean time (in days) between production date and examination date 
Table 2: Statistical analytical results of the different bacterial counts in the examined vacuum packed meat products.

\begin{tabular}{|c|c|c|c|c|c|c|c|c|c|c|c|c|}
\hline \multirow{3}{*}{$\begin{array}{c}\text { Microbial } \\
\text { counts }\end{array}$} & \multicolumn{12}{|c|}{ Vacuum packed meat products } \\
\hline & \multicolumn{3}{|c|}{ frankfurter } & \multicolumn{3}{|c|}{ pastrami } & \multicolumn{3}{|c|}{ rose beef } & \multicolumn{3}{|c|}{ beef bacon } \\
\hline & Min & Max & $\begin{array}{l}\text { Mean } \\
\pm \text { S.E }\end{array}$ & Min & Max & $\begin{array}{l}\text { Mean } \\
\pm \text { S.E }\end{array}$ & Min & Max & $\begin{array}{l}\text { Mean } \\
\pm \text { S.E }\end{array}$ & Min & Max & $\begin{array}{l}\text { Mean } \\
\pm \text { S.E }\end{array}$ \\
\hline $\begin{array}{l}\text { Psychro- } \\
\text { trophic }\end{array}$ & $5 \times 10^{6}$ & $8 \times 10^{8}$ & $\begin{array}{c}9.4 \times 10^{7} \pm \\
3.8 \times 10^{7}\end{array}$ & $10^{7}$ & $8 \times 10^{8}$ & $\begin{array}{c}2.9 \times 10^{8} \pm \\
6.4 \times 10^{7}\end{array}$ & $4 \times 10^{6}$ & $7 \times 10^{8}$ & $\begin{array}{l}1.3 \times 10^{8} \\
\pm 4 \times 10^{7}\end{array}$ & $2.1 \times 10^{6}$ & $6 \times 10^{8}$ & $\begin{array}{c}10^{8} \\
\pm 3 \times 10^{7}\end{array}$ \\
\hline $\begin{array}{c}\text { Lactic } \\
\text { acid } \\
\text { bacteria }\end{array}$ & $2 \times 10^{6}$ & $8 \times 10^{8}$ & $\begin{array}{c}1.6 \times 10^{8} \\
\pm 4.4 \times 10^{7}\end{array}$ & $3.1 \times 10^{7}$ & $7 \times 10^{8}$ & $\begin{array}{l}2 \times 10^{8} \pm \\
4.6 \times 10^{7}\end{array}$ & $3 \times 10^{6}$ & $3 \times 10^{8}$ & $\begin{array}{l}9.1 \times 10^{7} \pm \\
1.4 \times 10^{7}\end{array}$ & $10^{7}$ & $7 \times 10^{8}$ & $\begin{array}{c}10^{8} \pm \\
3.3 \times 10^{7}\end{array}$ \\
\hline $\begin{array}{c}\text { Anaerobic } \\
\text { bactria }\end{array}$ & $3.6 \times 10^{6}$ & $3 \times 10^{8}$ & $\begin{array}{l}9.7 \times 10^{7} \\
\pm 1.8 \times 10^{7}\end{array}$ & $3.4 \times 10^{7}$ & $4 \times 10^{8}$ & $\begin{array}{c}1.8 \times 10^{8} \pm \\
3.2 \times 10^{7}\end{array}$ & $4 \times 10^{7}$ & $6 \times 10^{8}$ & $\begin{array}{c}2.2 \times 10^{8} \pm \\
4.7 \times 10^{7}\end{array}$ & $3 \times 10^{6}$ & $4 \times 10^{8}$ & $\begin{array}{c}9.8 \times 10^{7} \\
\pm 2.3 \times 10^{7}\end{array}$ \\
\hline
\end{tabular}

Table 3: Incidence of isolated microorganisms from the examined vacuum-packed and packed meat products $(\mathrm{No}=10)$

\begin{tabular}{|c|c|c|c|c|c|c|c|c|c|c|c|c|c|c|}
\hline \multirow{3}{*}{ Isolates } & \multicolumn{4}{|c|}{ Frankfurter } & \multicolumn{4}{|c|}{ pasterami } & \multicolumn{4}{|c|}{ rose beef } & \multirow{2}{*}{\multicolumn{2}{|c|}{$\begin{array}{c}\text { beef bacon } \\
\begin{array}{c}\text { Vacuum } \\
\text { packed }\end{array}\end{array}$}} \\
\hline & \multicolumn{2}{|c|}{$\begin{array}{l}\text { Vacuum } \\
\text { packed }\end{array}$} & \multicolumn{2}{|c|}{ Packed } & \multicolumn{2}{|c|}{$\begin{array}{l}\text { Vacuum } \\
\text { packed }\end{array}$} & \multicolumn{2}{|c|}{ Packed } & \multicolumn{2}{|c|}{$\begin{array}{l}\text { Vacuum } \\
\text { packed }\end{array}$} & \multicolumn{2}{|c|}{ Packed } & & \\
\hline & No & $\%$ & No & $\%$ & No & $\%$ & No & $\%$ & No. & $\%$ & No & $\%$ & No & $\%$ \\
\hline S. aureus & 1 & 10 & 1 & 10 & ND & 0 & ND & 0 & ND & 0 & 2 & 20 & 2 & 20 \\
\hline L.monocytogenes & ND & 0 & ND & 0 & ND & 0 & ND & 0 & ND & 0 & ND & 0 & ND & 0 \\
\hline B. cereus & ND & 0 & 1 & 10 & ND & 0 & 1 & 10 & ND & 0 & ND & 0 & ND & 0 \\
\hline Cl. perfrengines & ND & 0 & ND & 0 & ND & 0 & ND & 0 & ND & 0 & ND & 0 & ND & 0 \\
\hline
\end{tabular}




\section{DISCUSSION}

Vacuum packing is one of the modified atmosphere packing methods that decrease oxygen content to very low limits while increase carbon dioxide contents to a relatively high content. This modification of the atmosphere results in changes in the predominant microflora and so the rate and pattern of spoilage. The spoilage may be caused by a wide range of reactions, including physical, chemical, enzymatic and microbial interactions (Gould, 1996).

The package protects products against deteriorative effects (Yam et al., 2005), which may include discoloration, off-flavor and off-odor development, nutrient loss, texture changes, pathogenicity, and other measurable factors (Skibsted et al., 1994). Modified atmosphere packaging (MAP) techniques are used in the food industry to extend the product shelflife. MAP can be classified into two main categories, namely, low oxygen modified atmosphere (including vacuum packaging, $\mathrm{CO}_{2}$ gas flushing, $\mathrm{N}_{2}$ gas flushing) and high oxygen modified atmosphere (Robertson, 1993).

The results of sensory assessment presented in Table (1) showed variable degrees of colour, odour and meat juice but most of the examined samples showed light pink colour, typical odour of meat, and only negligible amount of released juice. The sensory changes were markedly observed in frankfurter and beef bacon. The $\mathrm{pH}$ ranged between 5.2 and 6.16 , most of the examined samples had $\mathrm{pH}$ under 6 . Fermentation of saccharides by lactobacilli results in the production of lactic acid associated with a decrease of $\mathrm{pH}$ and an odour change. Lactic Acid Producing Bacteria are a component of the original microbial flora of meat that readily propagates on cooled and vacuum-packed meat. Their growth in red vacuum-packed meat stored in cooling rooms inhibits the propagation of G-bacteria. LAPB, via various mechanisms, inhibit the propagation of pathogenic bacteria (Hugas, 1998).

The results in Table (2) showed that the mean psychrotrophic counts for frankfurter, pastrami, rose beef and beef bacon were $9.4 \times 10^{7} \pm$ $3.8 \times 10^{7}, 2.9 \times 10^{8} \pm 6.4 \times 10^{7}, 1.3 \times 10^{8} \pm 4 \times 10^{7}$ and $10^{8} \pm 3 \times 10^{7} / \mathrm{g}$ respectively. The mean counts for lactic acid bacteria were, $1.6 \times 10^{8} \pm 4.4 \times 10^{7}, 2 \times 10^{8} \pm$ $4.6 \times 10^{7}, 9.1 \times 10^{7} \pm 1.4 \times 10^{7}$, and $10^{8} \pm 3.3 \times 10^{7} / \mathrm{g}$ respectively. Nearly similar results for psychrotrophic counts were reported by Blikstad and Molin (1983); El-Khawas (2001), also for lactic acid bacteria counts, results agreed with that reported by Samelis and Georgiadou (2000); El-Khawas (2001) in Frankfurter, Rose beef and Beef bacon.

Raw material was distinguished as the source of the major spoilage strains. Contamination of the product surfaces after cooking was shown to 
be airborne. The removal of the product from the cooking forms was localized as a major site of airborne lactic acid bacteria (LAB) contamination. Food handlers and some surfaces in contact with the product during the manufacture were also contaminated with the spoilage strains. Some strains were also able to resist cooking. These strains may have an effect on the product shelf life by contaminating the slicing machine (Bjorkroth and Korkeala 1997)

The microorganisms that are most commonly associated with refrigerated foods and cause food spoilage are psychrotrophs and not psychrophilis (Cousin et al., 1992).

Gill (1983) identified L. curvatus and $L$. sake as representatives of psychrotrophic microbial flora on vacuum-packed meat. Samelis et. al. (1998) revealed Lactobacillus sake and Leuconostoc mesenteroides spp. as the major causative agents of spoilage due to recontamination in the cutting room. Dykes et al. (1991) recorded that contamination of sausage surface by lactic acid bacteria occurred as a result of manufacturing and handling process.

Samelis and Georgiadou (2000) stated that mainly Lactobacillus sakei, dominated the microbial flora of industrially manufactured sausage. The isolation frequency of Lactobacillus sakei / curvatus from sausages stored anaerobically was as high as $92-96 \%$, on the other hand Ahn and Stiles (1990) isolated bacteriocins-producing lactic acid bacteria from vacuum-packaged meat stored at $4{ }^{\circ} \mathrm{C}$, which are antagonistic substances against Enterococcus spp. and Listeria monocytogenes. Bacteriocins differed in characteristics between strains, most of them still active after heat treatment at $62{ }^{\circ} \mathrm{C}$ for $30 \mathrm{~min}$, except for that of Leuconostoc strains and there is evidence that more than one bacteriocin-like substance may be produced by some strains. Growth medium, $\mathrm{pH}$ and growth temperature all affected the production of the inhibitory substances.

Regarding anaerobic bacteriae, Table 2 showed that their mean counts were $9.7 \times 10^{7} \pm 1.8 \times 10^{7}, 1.8 \times 10^{8} \pm 3.2 \times 10^{7}, 2.2 \times 10^{8} \pm 4.7 \times 10^{7}$ and $9.8 \times 10^{7} \pm 2.3 \times 10^{7} / \mathrm{gm}$ of frankfurter, pastrami, rose beef and beef bacon respectively. Nearly similar results for anaerobic counts in frankfurter, rose beef and beef bacon were reported by Hitchener et al. (1982); Blikstad and Molin (1983); El-Khawas (2001).

Number of bacteria on pastrami were slightly greater than frankfurter, rose beef and beef bacon, this agree with Holley and McKellar (1996) who found that numbers of bacteria on pastrami were significantly greater than on ham and bologna (pastrami > ham > bologna).

The obtained results illustrated that psychrotrophic count, lactic acid bacteria count and anaerobic count resembling each other to a great 
extent, this agree with Mcdaniel et al. (1984) who recorded that the total aerobic count was about the same as that of psychrotrophic count in all storage stages. In the same manner, psychrotrophic and anaerobic counts were almost identical with the total aerobic count (Blikstad and Molin, 1983). They added that the similarity of the results of different counts on different media and incubation conditions can be referred to the predominance of microflora by lactic acid bacteria. In vacuum packaging the microflora shift from predominance of Pseudomonas spp. to Lactobacillus spp. (95\% of flora).

Table (3) revealed that $S$. aureus could be isolated from vacuum packed frankfurter (10\%) and beef bacon (20\%) while L. monocytogenes could not be detected. Staphylococcal food poisoning due to vacuumpacked cooked meat products is relatively rare, although cases are known. S. aureus is frequently found in small numbers (about $10^{2} \mathrm{cfu} / \mathrm{g}$ ) on cooked meat (Varnam and Evans, 1991). Carmo et al. (2002) recorded that the food handlers are one of the most important sources of contamination by S. aureus which cause food poisoning outbreaks.

These results disagree with Abd Al-Hafize (1995); Mohamed (2000); El-Khawas (2001) who failed to detect $S$. aureus and attribute this result to the inhibition of $S$. aureus by lactic acid bacteria. Results agree with Sheridan, et al. (1995) who failed to detect L. monocytogenes. Also Samelis et al. (2000) pointed out that L. monocytogenes was always absent from the vacuum-packed product provided that heating to a core temperature of $70^{\circ} \mathrm{C}$ occurred and recontamination during slicing and packing was prevented, otherwise.

Krockel (1992) added that, L. monocytogenes was successfully inhibited in various culture media or in meat products by means of bacteriocin-forming Lactobacillus sake strain. Vacuum packing and storage under refrigeration is effective in controlling the growth of L. monocytogenes in sliced vacuum packed mortadella, indicating that good practices and implemented HACCP programs are essential to assure safety of this product (Bersot et al., 2008). On the other hand Katsaras and Dresel (1994) stated that L. monocytogenes counts increased throughout storage of the vacuum-packed sliced bologna-type sausage, in spite of development of high counts of lactic acid bacteria. Tobia et al. (1997) could identify five isolates as L. monocytogenes. They further added that the presence of this microorganism in this kind of product suggests environmental post-process contamination or insufficient thermal process.

Neither B. cereus nor $C l$. perfrengines could be detected in vacuum packed frankfurter, pastrami, rose beef and beef bacon respectively (Table 3). Similar results were reported by Ouf (2001) who failed to detect it in 
any of the examined heat-treated (frankfurter and luncheon) meat products. Moreover the presence of Lactobacillus spp. inhibit the growth of B. cereus and this mainly due to the presence of bacteriocin produced by the members of this species, which predominate in vacuum-packaged meat products (Suma et al., 1998).

On the other hand Juneja and Marmer (1996) stated that vegetative cells of $\mathrm{Cl}$. perfringens were not detected from a spore inoculum in vacuum-packaged even after 28 days of storage in the presence of 3\% salt. $\mathrm{Cl}$. perfringens growth was not observed at $4^{\circ} \mathrm{C}$ regardless of salt levels.

Also it is clear from Table (3) that $S$. aureus could be isolated from packed frankfurter and rose beef (10\% and $20 \%$ respectively). B. cereus could be isolated from packed frankfurter and pastrami (10\% for each). The low percentage of L.monocytogenes had been explained by Thevenot et al. (2006) who stated that the inefficiency of cleaning procedures to remove L. monocytogenes has associated with its ability to adhere to stainless steel and form biofilms.

Modified atmosphere packaging (MAP) has led the evolution of fresh and minimally processed food preservation, especially in meat and meat products for the past two decades. Packaging technology innovations and ingenuity will continue to provide MAP that is consumer oriented, product enhancing, environmentally responsive, and cost effective (McMillin, 2008).

\section{REFERENCES}

Abd Al-Hafize, E.M. (1995): Microbial and chemical evaluation of some heat treated meat products. Ph.D., Thesis, Fac. Vet. Med., Alexandria Univ.

Ahn, C. and Stiles, M.E. (1990): Antibacterial activity of lactic acid bacteria isolated from vacuum-packaged meats. J. Appl. Bacteriol. 69 (3): 302-310

Alisarlim, M.; Atasever, M. and Gokmen, M. (2005): Contamination of some vacuum packaged meat products with $L$. monocytogenesActa Alinentaria, ISSN 0139-3006 CODEN ACALDI 34(3): 331-334.

APHA "American Public Health Association" (1992): Compendium of Methods for the Microbiological Examination of Foods $3^{\text {rd }}$ ed. Vanderzant, C. and Splittstoesser, F. (Eds.) APHA Technical Committee on Microbiological Methods for Foods.

Bersot, L.D.S.; Gillio, C.; Tavolaro, P.; Landgraf, M.; Franco, B.G.D.M. and Destro, M.T. (2008): Behavior of L. monocytogenes in sliced vaccum packed mortadella. Braz. J. Microbiol. 39(3):142 
Bjorkroth, K.J. and Korkeala, H.J. (1997): Use of rRNA gene restriction patterns to evaluate lactic acid bacterium contamination of vacuumpackaged sliced cooked whole-meat product in a meat processing plant. Appl. Environ. Microbiol. 63 (2): 448-53.

Blickstad, E. and Molin, G. (1983): The microbial flora of smoked pork loin and frankfurter sausage stored in different gas atmospheres at 4 ${ }^{\circ} \mathrm{C}$. J. Appl. Bacteriol. 54: 45-56.

Brody, A.L. (2002): Meat packaging: past, present and future. In $55^{\text {th }}$ Ann. Recip. Meat Conf. East Lansing, MI, 28-31 July, Am. Meat Sci. Assoc., Urbana, IL.

Carmo, L.S.do; Souza-Dias, R.; Linardi, V.P.; Sena, M.J.de; Aparecidados-Santos, D.; Faria, M.E.de; Castro-Pena, E.; Jett, M. and Heneine, L.G. (2002): Food poisoning due to enterotoxigenic strains of Staphylococcus present in Minas cheese and raw milk in Brasil. Food Microbiol., 19(1): 9-14.

Cousin, M.A.; Jay, J.M. and Vasavada, P.C. (1992): Psychrotrophic microorganisms In "Compendium of Methods for the Microbiological Examination of Foods" Eds.Vanderzant, C. and Splittstoesser, D.F. APHA Technical Committee on Microbiological Methods for Foods, Washington, DC.

Dykes, G.A.; Cloete, T.E. and Holy, A. Von (1991): Quantification of microbial populations associated with the manufacture of vacuumpackaged smoked Vienna sausages.International J. Food Microbiol. 13 (4): 239-248.

El-Khawas, K.M.S. (2001): Studies on vacuum packed meat products $\mathrm{Ph}$. D., Thesis, Fac. Vet. Med., Zagazig Univ.

Farkas, J.; Andrassy, E. and Horti, K. (1996): Extension of shelf-life of a vacuum-packed chilled meat product by combination of gamma radiation, ascorbic acid and sodium lactate. Radiayion Physics and chemistry, 48 Issue 3, (382-382).

FDA (2001): Detection and Enumeration of Staph. aureus in Foods. In: Bacteriological analytical manual online. By Bennett, R.W. and Lancette,G.A., $8^{\text {th }}$ Ed., US FDA, Ch. 12.

FDA (2003): Detection and Enumeration of Listeria monocytogenes in Foods. In: Bacteriological Analytical Manual online. By Hitchins, A. D, $8^{\text {th }}$ Ed. US FDA.

Garcia de Fernando, G.D.; Nychas, G.-J.E.; Peck, M.W. and Ordonez, J.A. (1995): Growth/survival of psychrotrophic pathogens on meat packaged under modified atmospheres. Int. J. Food Microbiol. 28, 221-232. 
Gibbs, B.M. and Freame, B. (1965): Methods for the recovery of clostridia from foods. J. Appl. Bacterio. 28: 95.

Gill, C.O. (1983): Meat spoilage and evaluation of the potential storage life of fresh meat. J. Food Port. 46: 444-452.

Gould, G.W. (1996): Methods for preservation and extension of shelf life. Int. J. Food Microbiol. 33: 51-64.

Han, J.H. (2005): New technologies in food packaging: Overview. In J. H. Han (Ed.), Innovations in food packaging (pp. 3-11). Amsterdam: Elsevier Academic Press.

Hayes, P.R. (1992): Food microbiology and hygiene. In Food poisoning and other food borne hazards. $2^{\text {nd }}$ ed. Elbs and Edward Arnold Publisher, London \& N.Y.

Hitchener, B.J.; Egan, A.F. and Rogers, P.J. (1982): Characteristics of lactic acid bacteria isolated from vacuum-packed beef. J. Appl. Bacteriol. 52: 31-37.

Holley, R.A. and McKellar, R.C. (1996): Influence of unsliced delicatessen meat freshness upon bacterial growth in subsequently prepared vacuum packed slices. Int. J. Food Microbiol. 29 (2-3): 297-309

Hotchkiss, J.H. (1988): Experimental approaches to determining the safety of food packaged in modified atmospheres. Food Technology, 42(9), 55-64.

Hugas, M. (1998): Bacteriovinogenic lactic acid bacteria for the biopreservation of meat and meat products. Meat Sci. 49: 139-150.

Huis In't Veld, J.H.J. (1996): Microbial and biochemical spoilage of foods: overview. Int. J. Food Microbiol. 33: 1-18

Ingham, S.C.; Engel, R.A.; Fanslan, M.A.; Schoeller, E.L.; Searls, G.; Buege, D.R. and Zhu, J. (2005): Fate of S. aureus on vacuum packaged ready to eat meat products stored at $21 \mathrm{C}^{\circ} \mathrm{J}$. Food Prot. 68(9): 1911-1915.

Juneja, V.K. and Marmer, B.S. (1996): Growth of Cl. perfringens from spore inocula in sous-vide turkey products. J. Food Microbiol. 32 (1-2): 115-123.

Katsaras, K. and Dresel, J. (1994): Effect of added soy protein on bacterial growth in vacuum-packed, sliced Bolonga-type sausage. Fleischwirtschaft 74 (12): 1317-1319

Kerry, J.P.; O'Grady, M.N. and Hogan, S.A. (2006): Past, current and potentialutilization of active and intelligent packaging systems for meat and musclebased products: A review. Meat Science, 74, 113-130.

Krockel, L. (1992): Bacteriocine von Milchsaurebakterien fur Fleischerzeugnisse. Mittbl. BAFA Kulmbach 32, 21-25. 
Mcdaniel, M.C.; Marchello, J.A. and Tinsley, A.M. (1984): Effect of different packaging treatments on microbiological and sensory evaluation of precooked beef roasts. J. Food Prot. 47 (1): 23-26.

McMillin, K.W.; Huang, N.Y.; Ho, C.P. and Smith, B.S. (1999): Quality and shelf-life of meat in case-ready modified atmosphere packaging. In Y.L. Xiong, F. Shahidi, \& C. T. o (Eds.), Quality attributes in muscle foods (pp. 73-93). New York: ACS Symposium Series, Plenum Publishing Corporation.

McMillin, K.W. (2008): Where is MAP Going ? A review and future potential of modified atmosphere packing for meat. Meat Science 80: 43-65.

Mohamed, E. (2000): Quality investigation into beef frankfurter produced in Egypt. M. V. Sc., Thesis, Fac. Vet. Med., Cairo Univ.

Napravnikova, E.; Vorlova, L. and Malota, L. (2002): Changes in Hygienic Quality of Vacuum-packed Pork During Storage. Acta Vet. Brno, 71: 255-262.

Ouf, J.M. (2001): Microorganisms of sanitary importance in some meat products and their additives. Ph.D., Thesis, Fac. Vet. Med., Cairo Univ.

Pipek, P. (1995): Bakteriociny v masne vyrobe. Maso (6) 30-35.

Ray, B.; Kalchayanand, N. and Field, R.A. (1989): Isolation of a Clostridium spp. from spoiled vacuum-packaged refrigerated beef and its susceptibility to bcateriocin from Pediococcus acidilactici. Proceedings International Congress of Meat Science and Technology 35 (II): 285-290.

Renerre, M. and Labadie, J. (1993): Fresh red meat packaging and meat quality. In Proceedings 39th international congress of meat science and technology (pp.361-387), 1-6 August 1993, Calgary, Canada.

Robertson, G.L. (1993): Food packaging: Principles and practices. New York, NY: Marcel Dekker Inc.

Samelis, J. and Georgiadou, K.G. (2000): The microbial association of Greek taverna sausage stored at 4 and $10^{\circ} \mathrm{C}$ in air, vacuum or $100 \%$ carbon dioxide, and its spoilage potential. J. Appl. Microbiol. 88 (1): 58-68.

Samelis, J.; Kakouri, A. and Rementzis, J. (2000): Selective effect of the product type and packaging conditions on the species of lactic acid bacteria dominating the spoilage microbial association of cooked meats at $4^{\circ} \mathrm{C}$. Food Microbiol., 17: 329-340. 
Samelis, J.; Kakouri, A.; Georgiadou, K.G. and Metaxopoulos, J. (1998): Evaluation of the extent and type of bacterial contamination at different stages of processing of cooked ham. J. Appl. Microbiol. 84 (4): 649-60.

Sheridan, J.J.; Dohertym, A.; Allen, P.; McDowell, D.A.; Blair, I.S. and Harrington, D. (1995): Investigations on the growth of L. monocytogenes on lamb packaged under modified atmospheres. Food Microbiol., 12 (3): 259-266.

Skibsted, L.H.; Bertelsen, G. and Qvist, S. (1994): Quality changes during storage of meat and slightly preserved meat products. In Proceedings 40th international congress of meat science and technology (S-II.MP1 pp. 1-10). 28 August-2 September 1994, The Hague, Netherlands.

Suma, K.; Misra, M.C. and Varadaraj, M.C. (1998): Plantaricin LP84, a broad spectrum heat-stable bacteriocin of Lactobacillus plantarum NCIM 2084 produced in a simple glucose broth medium. Int. J. Food Microbiol. 40 (1-2): 17-25.

Thevenot, D.; Dernburg, A. and Vernozy-Rozand, C. (2006): An updated review of Listeria monocytogenes in the pork meat industry and its products. J. Appl. Microbiol., 101, 7-17.

Tobia, M.B.; Mengoni, G.B. and Pellon, H.S. (1997): Listeria monocytogenes and Listeria species in heat-processed products. Rev Argent Microbiol., 29 (2): 109-113.

Tsigarida, E. and Nychas, G.J.E. (2001): Ecophysiological attributes of Lactobacillus sp. and Pseudomonas sp. on sterile beef fillets in relation to storage temperature and film permeability. J. Appl. Microbiol. 90: 696-705

Varnam, A.H. and Evans, M.G. (1991): Food borne pathogens. Wolfe Publishing Ltd. Pp 459-460.

Yam, K.L.; Takhistov, P.T. and Miltz, J. (2005): Intelligent packaging: Concepts and applications. J. Food Science, 70(1): 1-10. 